\title{
Ernst Bloch as a Philosopher of Praxis
}

Contrary to the widespread portrayal of Bloch's philosophy as "mystical," "eschatological," "idealistic" etc., the essay shows that it is best interpreted through the framework of a Marxist philosophy of praxis. Similarly, to Labriola and Gramsci, Bloch develops his concept of materialism from Marx's Theses on Feuerbach. His concepts of the "highest good" and of an "alliance technique" take up young Marx's perspective of a reconciliation between humans and nature; his theory of anticipation and hope is centered on the development of collective capacities to act; even his "ontology of the not yet," which is often criticized for its teleology, is actually based on the concept of "open possibilities" and can thus be interpreted in terms of the "weak teleological force of open possibilities." However, from a praxis-philosophical perspective, Bloch's philosophy is also in need of a rethinking that overcomes its essentialist presumptions and pluralizes its teleology.

Keywords: Anticipation, Hegemony, Hope, Ontology, Teleology 
After the Hungarian uprising of 1956, the German Democratic Republic's party and state leadership branded Ernst Bloch a dissident and declared his philosophy to be utopian, idealistic, mystic-pantheistic, and thus no longer Marxist. In 1957, he was forced into retirement. As a consequence he moved to Western Germany and started to teach in Tübingen. Against the backdrop of Bloch's oppressive marginalization, it is astonishing that many of the reproaches utilized to justify his exclusion from Marxism are unhesitatingly rehashed in recent scholarship. Whatever the corresponding value judgment, Bloch's philosophy is again portrayed by many as "idealistic," "eschatological," "metaphysical" or "mystical". Whereas Bloch tried to "inherit" the utopian impulses of religion in his perspective of a "transcending without any heavenly transcendence but with an understanding of it" (Bloch 1986, 1288), his dialectical critique of religion continues to be drawn back into the orbit of a religious enthusiasm. Hans-Ernst Schiller attributes to Bloch a "utopian, metaphysical-religious philosophy" with eschatological characteristics (Schiller 2017, 35). According to Terry Eagleton, Bloch's philosophy is a "mystical materialism" which "has smuggled quasi-divine properties into [matter]" (Eagleton 2015, 98-99). As Beat Dietschy observes, there is a widespread tendency to transform "what Bloch had held in suspense or considered as an open horizon of problems" into something unambiguously theological or teleological. "When he spoke of the possibilities of nature with which human purposes can ally or which social praxis could set free, it was interpreted as an objective teleology of the world process" (Dietschy 1988, 88).

Against the manifold attempts to sever one of Marxism's most creative philosophers from its traditions, I propose that Bloch's approach is best understood as an original contribution to a philosophy of praxis. The term was first coined by Antonio Labriola and further developed primarily by Antonio Gramsci. Both referred back to Marx's Theses on Feuerbach, whose first thesis contained the criticism that "all previous materialism" had conceived of reality "only in the form of the object, or of contemplation, but not as a sensuous human activity, practice, not subjectively" (Marx 1845, 3). It is no coincidence that Bloch also developed his concept of materialism against a static understanding of Klotzmaterie (clod matter) (Bloch 1985a, 17) from the Theses on Feuerbach. The Archimedean point of his materialism is the "working people" in their "social modes of satisfying needs" and in their relations "to people and to nature" (Bloch 1986, 286). Bloch's comprehensive concept of matter thus includes "consciousness" and "spirit" (Bloch 1985c, 234), which have been treated by traditional philosophy (and also "Marxism-Leni- 
nism") as antipodes to "matter". As soon as one reads Bloch from a praxis-philosophical angle, one encounters numerous intersections with Gramsci which are all the more astonishing as the two were of course not familiar with each other's works.

I will divide my argument into two main parts. First, I will demonstrate the fruitfulness of a praxis-philosophical re-reading of both Bloch's anthropology and ontology. Underlying his concept of anticipation and the "not-yet-conscious" is a materialist, body-centered theory of agency; Bloch's daydream analyses can be read together with Gramsci's concept of "good sense," based on which the bizarrely composed common sense can be rendered more coherent; and his "ontology of the not yet" offers a complex interaction between a "strong teleology" and what I propose to call a weak teleological force of open possibilities. Second, I will discuss some weak points in Bloch's philosophy that need to be overcome or modified. His long-term utopian goals should not be formulated in terms of an "identity" without contradictions, but rather in terms of a contradictory process of transformation and reconciliation; and some essentialist and teleological presumptions need to be modified, for example, by connecting them with a Gramscian analysis of the respective hegemonic conditions for hope and hopelessness.

\section{Anticipation and Hope}

Some difficulties of interpretation are due to the fact that most of Bloch's concepts reach far back into his pre-Marxist early work and then experience a turn after his encounter with Marxism that gives them a new and specific meaning. A careful analysis needs to account for both aspects. A key concept of Bloch's anthropology, the human capacity of "anticipation", is a case in point: it can be traced back to his early works and thus associated with messianic, mystical, romantic, Goethian or neo-Kantian traditions (Rehmann 2012, 3ff). Bloch himself reports that the idea of a Not-Yet-Conscious struck him in 1907 at the age of 22 (Bloch 1975, 300). But in the Principle of Hope, when he proceeds to transform the different aspects of anticipatory consciousness into a systematic concept of his anthropology, his understanding of Marxism plays a decisive role. Bloch quotes Marx's famous portrayal of the worst human architect, who is distinguished from the best of bees in that he „builds the cell in his mind before he constructs it in wax. At the end of every labour process, a result emerges which had already been conceived by the worker at the beginning, hence already existed ideally" 
(Marx 1976, 284). According to Bloch, it is "precisely at this point" that wishes and daydreams are formed (Bloch 1986, 76). Rather than having established an omni-historical and therefore "bourgeois" anthropological notion of human essence, as per official GDR-Marxism criticism of him, Bloch referred to some of the phylogenetical conditions that allow humans to actively participate in the respective social ensemble. Critical Psychology has conceptualized this as "societal nature" or "natural potentiality to sociality," which developed with the emergence of human labor, cooperation and language (Holzkamp 1985, 180). It is true that elementary capacities to anticipate future events can be observed in the animal world as well, but they receive a new quality and scope in cooperative human practices (Holzkamp 1985, 142ff, 260ff).

It is from this capacity of anticipation that Bloch construes his theory of affects. The affects ascend from urging to longing to wishing to wanting, which has already actively decided about preferential options - it is a "wanting to do" (Bloch 1986, 46-47). Against the widespread tendency of considering the drives as autonomous forces, Bloch proposes to reconstruct them from the point of view of the body: the human being is "an equally changeable and extensive complex of drives, a heap of changing, and mostly badly ordered wishes," often moving like "opposing winds around a ship" (Bloch 1986, 50), but "present throughout is only the body which wants to preserve itself" (Bloch 1986, 49).

The quality and scale of anticipation also help distinguish our "expectant" emotions from short-term "filled emotions" (Bloch 1986, 74). The ascending line then culminates in hope, which is "the most human of all mental feelings" (Bloch 1986, 75). Some critics argue that Bloch is simply projecting his political perspective onto his anthropology, which is thus subjugated to an externally determined teleology. What is overlooked in such a critique is the fact that Bloch founds his argument on a concept of agency directed towards the world, which is inspired by the ethics of Spinoza, particularly his distinction between feelings that we are passively subjected to (passionibus) and self-determined feelings driven by an enlargement of potentia agendi, our capacity to act. From this perspective, anxiety is not an ontological existential, as Heidegger wants it to be, but a "suffering, oppressed, unfree" emotion imposed on us (Bloch 1986, 75).

The linchpin of Bloch's anthropology is the development of cooperative agency. On the first page of Principle of Hope, he lays out that hope "goes out of itself, makes people broad instead of confining them." It "requires people who throw themselves actively into what is becoming, to which they themselves belong. It will not tolerate a dog's life which 
feels itself only passively thrown into What Is" (Bloch 1986, 1). To throw oneself actively into what is becoming is of course a polemic against Heidegger's notion of "thrownness". Whereas Heidegger generalizes and ontologizes anxiety, elevating it to be a path towards "authentic" existence, Bloch develops the notion of a "comprehended hope" (docta spes) that can be informed and corrected by observation and analysis (Bloch 1986, 7).

\section{From people's daydreams to a Marxist "doctrine of warmth"}

Bloch's proposal that through the learning of hope we can overcome our state of confusion and anxiety (Bloch 1986, 1), can be compared to Gramsci's project of working on the coherence of our common sense, which is characterized by its contradictory and bizarre composition. It "contains Stone Age elements and principles of a more advanced science, prejudices from all past phases of history ... and intuitions of a future philosophy which will be that of a human race united the world over" (Gramsci 1971, 324). In Heritage of Our Times, Bloch analyzed with a congenial intuition such historic discrepancies as contradictions of "non-contemporaneity" (Ungleichzeitigkeit). These non-contemporeneous contradictions are replete of undischarged future embedded in the past, which have been captured by the Nazis and need to be reclaimed by a multilayered and multitemporal dialectics (Bloch 1991, 97ff, 113). Both Gramsci and Bloch were searching for anchorage points in everyday life from which to transform contradictory common sense. Gramsci called this anchorage point good sense (buon senso), the healthy nucleus of common sense, characterized by direct observation and an open sense of experimentation (Gramsci 1971, 328, 348). "Organic intellectuals" of the subaltern classes must connect their philosophy of praxis with this good sense so that they can help elevate people's common sense to a more coherent level (Gramsci 1971, 326; Gramsci 1975, Q11, \$12). And indeed, Bloch uses the two terms in a similar way when he states that the typically undialectical common sense is not sound at all but full of petit-bourgeois prejudices, whereas good sense is a "mark of fullness, of truly sound sobriety, [which] does not rule out any perspectives", except the detrimental ones (Bloch 1986, 1368).

For Bloch, the specific good sense anchorage points are the daydreams by which "everybody's life is pervaded" (Bloch 1986, 1). Referring back to Marx's remark, "that the world has long dreamed of possessing something of which it has only to be conscious in order to possess it in reality" 
Bloch scholars are often

so fixated on Bloch's distant "eschatological" goals that they overlook

his methodological claim to develop utopian elements out of

the most proximal realities: "the Here and Now, what is repeatedly beginning in nearness, is a utopian category, in fact the most central one" (Bloch 1986, 12).
(MECW 3, 144), Bloch developed his monumental project of deciphering the history of the human dream. The inquiry ascended from the roasted pigeons of the land of Cockaigne to social utopias and natural right theories, to poetry, architecture, music and religion. What makes these diverse materials "speak" is Bloch's sense for the rebellious and liberative dimensions they contain in revealing the "pre-appearance" of a classless society without domination and alienation.

Bloch scholars are often so fixated on Bloch's distant "eschatological" goals that they overlook his methodological claim to develop utopian elements out of the most proximal realities: "the Here and Now, what is repeatedly beginning in nearness, is a utopian category, in fact the most central one" (Bloch 1986, 12). According to Enrique Dussel, Bloch develops a particular materialistic method that starts from "living being [ser-vivente] in connection to a possible new future" (Dussel 2013, 335f). And it is specifically in his aphorisms on daydreams that he precisely observes what at times gets lost in the more general parts of his philosophy, namely, the extent to which everyday wishes are overdetermined by class rule and its ideologies: the wishful images in the mirror often only reflect "how the ruling class wishes the wishes of the weak to be" (Bloch 1986, 13), "the threatened man looks at himself with the eyes of his master," and when he puts himself at an advantage, it is actually "the advantage which the real masters gain from the little man" (Bloch 1986, 340). In short, many of the small daydreams are related to "present life that should just yield a better pay-off" (Bloch $1975,42)$. Nevertheless, what qualifies them as anchorage points of "good sense" is their anticipatory potential: "even the most private and unknowing wishful thinking is to be preferred to the unconscious walking in single file; because it can be informed" (Bloch 1986, 1365; transl. altered).

The arc leading from Bloch's notion of daydreams to his Marxist "doctrine of warmth" cannot be explained primarily from his early pre-Marxist works, but rather from the operative strategy by which he intervenes in the contentious force field of Marxism. The context of this intervention is first, the worldwide split of the labor movement between social-democracy and the Communist International, and second, a narrowing and atrophying of anticipatory potentials, which he perceives on both sides of this split. Indeed, the "Marxism" received by the labor movement in both the "reformist" and the "revolutionary" factions was primarily understood as a "science of the laws of history" and a "doctrine of development” (see Rehmann 2014, 61ff).

Therefore, Bloch had good reasons to bend the stick in the opposite direction. In Heritage of Our Times, he criticized determinism and one- 
-sided rationalism as Marxism's main shortcomings, which served to facilitate the ideological appeal of fascism, its successful "thefts from the commune" (Bloch 1991, 64). When "vulgar Marxism had forgotten the inheritance of the German Peasant Wars and of German philosophy, the Nazis streamed into the vacated, originally Münzerian regions" (Bloch $1991,140)$. He concluded that Engels' proclamation of socialism's progress from utopia towards science led to an "undernourishment of revolutionary imagination" so that "the pillar of fire in utopias [...] could also be liquidated along with the cloud" (Bloch 1986, 622). Against this backdrop, Bloch's philosophy is to be understood as a project to reconnect the split-off utopian impulses with the analytical achievements of Marxist critique. Bloch extended Marxist theory so that it is able to reintegrate both sides and put them in a dialectical combination. The determinate negation of Marxist critique is reframed as "cold stream," characterized by a concrete "science of condition [...] of struggle and opposition," coupled with an "unmasking of ideologies" and a "disenchantment of metaphysical illusion" - an indispensable caveat against utopian tendencies of "overhauling, skipping over, flying over" (Bloch $1986,208)$. The concept of „warm stream” explores and articulates the liberating intentions that are oriented towards a "utopian totum” in which humans, their world and nature are no longer alienated from each other (Bloch 1986, 209). As a "doctrine of warmth", Marxism becomes a "theory-praxis of reaching home" (Bloch 1986, 209-210.). Similar to Rosa Luxemburg, who tried to reconnect the distant revolutionary goals and the closer goals of realistic reforms by her famous formula of "revolutionary Realpolitik" (Luxemburg 1970-5, Vol. 1/1, 373), Bloch described the two sides of progressive politics both as a contradiction - acerbity vs. faith (Bloch 1986, 208) - and as a complementary connection: "Only coldness and warmth of concrete anticipation together [...] ensure that neither the path in itself nor the goal in itself are held apart from one another undialectically and so become reified and isolated" (Bloch 1986, 209).

\section{Summum bonum, the highest good}

Bloch's formulations of distant utopian goals are mainly inspired by the young Marx's perspective in the Economic and Philosophic Manuscripts of 1844 in which the overcoming of alienation in a classless society does not only apply to relationships among humans, to their labor and their potential as a species, but must also comprise a reconciliation with nature to which they belong: the communist society is characterized by "the 
complete unity of man with nature - the true resurrection of nature the accomplished naturalism of man and the accomplished humanism of nature" (MECW 3, 298). Thus, this anticipated reconciliation between humans, their world and nature becomes the core of Bloch's concept of the "highest good" (summum bonum). The most diverse hope images designate a "peak of the dreams of a better life" (Bloch 1986, 305): there is an "irrefutable feeling that the better cannot be surpassed infinitely", that there must be a fulfilling "thus far and no further" (Bloch 1986, 1313). What was expressed traditionally as "God", the "kingdom of God" or the "realm of Freedom" is "the identity of man who has come to himself with his world successfully achieved for him" (Bloch 1986, 313).

The usual portrayal of Bloch's ultimum and summum bonum as a quasi-religious eschatology (see Holz 2012, 503, 507) misses the point that Bloch's this-worldly translation of "last things" does not provide a savior nor a guarantee. According to Johan Siebers, Bloch tried to express the eschatological principle "the last hour remains hidden" in a "tentative image [Versuchsgestalt] of identity" of existence and essence, or "Heimat" (Siebers 2012, 582, 587). However, this leads to the paradox that as soon as one interprets such a "tentative image" in an empirical way, one is confronted with the problem that any completely achieved "identity" would result in an entropic standstill, which is in turn incompatible with a dialectical understanding of history driven by contradictions. Bloch himself was aware of this methodological problem and described it as one of the "true materialist aporias and antinomies" (Bloch 1985a, 116): the highest good "does not encounter the process with its transitorinesses, and consequently is not encountered by them either," because any achieved identity "would no longer enter [...] into any process, $[. .$.$] there would no longer be any occasion for process"$ (Bloch 1986, 1179). However, if Bloch's ultimate goal is "exterritorial to the process", as Siebers argues (Siebers 2012, 588), it assumes a similar status to Kant's "regulative idea”. But this Kantian interpretation contradicts Bloch's objection that Kant's postulate of a fundamental elusiveness of the highest good reveals an "abrupt undialectical dualism" establishing an insurmountable barrier between a disconnected ideal and a remote ideal and reality (Bloch 1986, 1320 et sq.).

The praxis-philosophical relevance of Bloch's summum bonum can be seen in the way he reformulates the young Marx's notion of a reconciliation between humankind and nature in terms of a "technology of alliance [Allianztechnik], which is mediated with the co-productivity of nature" (Bloch 1986, 690). Whereas “our technology up to now stands 
in nature like an army of occupation in enemy territory", without knowing the interior of the country (Bloch 1986, 696), a "Marxism of technology" has as its task to end "the naive application of the standpoint of the exploiter and animal tamer to nature" and to forge a non-exploitative "nature alliance" (Naturallianz) that frees up "the creations slumbering in the womb of nature" (Bloch 1986, 695; see Bloch 1985d, 251). The objective is an "unparalleled hook-up [Verhakung]..., a real installation of human beings (as soon as they have been socially mediated with themselves) into nature (as soon as technology has been mediated with nature)" (Bloch 1986, 698).

What is at stake in the summum bonum is what we could call an eco-socialist perspective. Notwithstanding some illusions regarding technological progress in the Soviet Union finally freed from capitalistic "fetters", and in particular Bloch's support for a peaceful use of nuclear energy without considering the still unresolved problem of the permanent disposal of nuclear waste (Bloch 1986 660, 663f), his concept of alliance technology can be seen as a theoretical alternative to the environmental destruction in the "Capitalocene". Bloch's philosophy of nature is certainly not without speculative exaggerations (see below), but his basic argument regarding a connection of nature's and human history contains valid insights. It resurfaces in recent ecological theories, which characterize this relationship as "co-evolution" (see Foster 2010, 230, 239, 247, 262). The Marxist concept of human praxis needs to be deepened so that it includes our natural roots in the past and present and places the orientation towards sustainable human-nature relationships in the center of the humanum (see Haug 2017, 9f).

\section{Can we read Bloch's "Ontology of the Not-Yet" in a praxis-philosophical key?}

Bloch, who already as a student desired to design an overall philosophical system "against which the Hegelian system would look like a doghouse" (Zudeick 1987, 48), also inscribed his Marxist philosophy of praxis in the framework of a classic system philosophy. It is clear that such an inscription did not come without speculative risks. He took up traditional philosophical concepts—origin, essence, teleology, identity, highest good etc. - severed them from their dependency on pre-given objectives and redefined them from the perspective of an "ontology of the not-yet", according to which the "true genesis is not at the beginning but at the end" (Bloch 1986, 1375). Whether we consider Bloch's
The Marxist concept of human praxis needs to be deepened so that it includes our natural roots in the past and present and places the orientation towards sustainable human-nature relationships in the center of the humanum (see Haug 2017, 9f). 
ontology, as Lukács did, as a non-Marxist "utopian system" (see Bloch 1975, 33-34) or as a materialist anchorage of this anthropology in reality, depends first and foremost on whether we read it as a teleology engrained in history and nature or rather in the hermeneutical key of open possibilities. Both readings can be supported by quotes, at times within the same sentence. It seems that Bloch wrote in both keys at the same time and used the ambiguity as a subversive stylistic means to force "these petrified relations [...] to dance by singing their own tune to them" (MECW 3, 178).

Adorno applied one of the hermeneutic keys when he called Bloch an "idealist malgré lui". He criticized an "innermost antinomy" of Bloch's thought, namely that it "conceives the end of the world as its ground, that which moves what exists, which, as its telos, it already inhabits" (Adorno 1991, 213). Eberhard Braun objected to this interpretation and argued that Bloch's telos had not the status of a necessity, but belonged to the mode of possibility, whose reality was not yet decided (Braun 1983, 124f, 128, 131). Indeed, when Bloch's anthropology transitions to an "Ontology of the Not-Yet" in the $17^{\text {th }}$ and $18^{\text {th }}$ chapters of the Principle of Hope, the argument is centered on the concept of "real possibility", in which utopian imagination finds its "concrete correlate" in the world (Bloch 1986, 197). On the side of the subjective factor, we find an active possibility, a capability-of-doing-other, a potency to turn things, while on the side of the objective factor we find a passive possibility, capability-of-becoming-other, potentiality, turnability, changeability of the world (Bloch 1986, 232-233, 247). The traditional version or teleology, according to which the purpose is preordained at the beginning and exists there "according to its, disposition' [Anlage] in reduced form, as if encapsulated" is thus rejected, but Bloch holds on to a "genuine teleology problem itself," whose purposes "are only just forming in active process, always arising anew within it and enriching themselves" (Bloch 1986, 1373-1374). Certainly, some expressions like "entelechetical latency", or "disposition" (Anlage) or "urge of the material” (Bloch 1985a, 464, 474-475; Bloch 1986, 18) seem to suggest that the goals are already embryonically contained in reality, which might motivate Eagleton's quip that according to Bloch's ontology, communism is already "implicit in the structure of the amoeba" (Eagleton'2015, 99). But Bloch also turns explicitly against such an in-built entelechy, e.g. when he argues that the humanization of nature "has no parental home at the beginning from which it runs away and to which, with a kind of ancestor cult in philosophy, it returns" (Bloch 1986, 204). When he uses the term "seed" (Keim), he does so in quotation marks and adds 
that it "awaits many leaps," while the "inherent propensity" (Anlage), again in quotation marks, "unfolds itself in the unfolding itself to ever new [...] beginnings of its potentia-possibilities" (Bloch 1986, 238). He thus takes up the traditional terms Keim and Anlage and defines them in a way that playfully subverts their traditional meaning. ${ }^{1}$

Furthermore, Bloch's teleology is disrupted by the fact that the key concepts of his philosophy - the ultimum, latency, tendency, novum etc. - are by no means necessarily directed toward a good outcome, but are shot through by the alternative between "salvation" and "disaster." They contain the possibility of an "absolute In-Vain of the historical process," the "sealed frustration of utopia" (Bloch 1986, 312-313), a "latency of Nothing" which designates what was traditionally called evil and announces itself as annihilation, disintegration, threatening chaos (Bloch 1986, 1296), exemplified by "the eruption of fascist hell" (Bloch 1986, 233). The positive outcome of the possible can only become a reality when it has an "active hope as an ally" (Bloch 1985a, 141), the objective factors of potentiality are reliant on the "capacity, the potency of the actualizing subject" (Bloch 1985a, 255).

This explains the vehemence with which Bloch criticizes the "automatic progress-optimism" as a "new opium for the people," to which "even a dash of pessimism would be preferable" because "at least pessimism with a realistic perspective is not so helplessly surprised by mistakes and catastrophes, by the horrifying possibilities [...] precisely in capitalist progress" (Bloch 1986, 198-199). This resembles Gramsci's critique of "mechanical determinism" as a "substitute for the Predestination" and a "religion of the subaltern", which means that the "activity of the will" is present "only implicitly, and in a veiled and, as it were, shamefaced manner” (Gramsci 1971, 336f). And when Bloch proposes to combine a "thinking ad pessimum" with a "militant optimism" (Bloch 1986, 199), he describes a similar attitude of working in and with contradictions as expressed in Gramsci's famous formula "pessimism of the intelligence, optimism of the will” (Gramsci 1975, 1131).

As soon as we read Bloch's ontology of the not-yet in the key of open possibilities, we discover something that is clearly distinguished from the catchwords of a "matter driving forwards", equipped with its own (though only hypothetical) "nature subject" and "utopia" (Bloch 1985c, 207; Bloch 1985d, 251). Beneath this "strong" teleology, there is a much

1 According to Cat Moir, Bloch's teleology is one "without a pre-given telos, in which the goal itself, the 'essence' of what the world might be, is still being worked out in a complex dialectical process of becoming from which contingency and chance are [...] far from absent" (Moir 2019, 72). 
Concrete hope, which does not give up when faced with setbacks, presumes that possibilities are still open and the world remains an "experimenting laboratory possibilis salutis" (Bloch 1985b, 389, 391). more modest and careful orientation toward the not-yet, which by referencing Walter Benjamin's "weak messianic force" (Benjamin 2007, 254), we might characterize as a weak teleological force of open possibilities. Its core is that "it is not yet the evening to end all days, every night still has a morning" (Bloch 1986, 305). Even well-founded hope contains "eo ipso the precariousness of failure", because it stands in the undecidedness of the world process (Bloch 1985b, 387). Concrete hope, which does not give up when faced with setbacks, presumes that possibilities are still open and the world remains an "experimenting laboratory possibilis salutis” (Bloch 1985b, 389, 391).

Taking Bloch's philosophy seriously also means critically confronting it with the challenges of the $21^{\text {st }}$ century. It is obvious that Bloch had long repressed the crimes of Stalinism. It was only from 1956 that he recognized the extent of the deformations of Soviet state socialism. ${ }^{2}$ However, its ultimate downfall, which impacts our "post-socialist" age, was not foreseeable for him. His self-understanding of being an organic intellectual of a socialist labor movement, which saw capitalist society in decline and itself in the ascendant in spite of all the setbacks and defeats, certainly set the tone of his writings. We need to take the historical distance between Bloch's time and our post-1989-era into consideration when we evaluate and update his philosophy today. The following four theses deal with the question of what is still relevant today and what is in need of a correction and renewal.

1. Even if under the conditions of neoliberal capitalism seemingly without alternative, we agreed with Habermas' diagnosis that there is an "exhaustion of utopian energies" (Habermas 1985, 144f), this would not be a valid argument against a philosophy of the Not-Yet, which deciphers the utopian impulses in people's daydreams and the big "outlines of a better world." This also applies to Bloch's courage to take up and to think through the different utopias of a summum bonum. Leftist projects and social movements should not be content with living "hope-lessly in the present" (Thürmer-Rohr 1991, 22), but need to develop appealing, convincing and powerful counter-images of a "good life."

2 According to a friend's report, he collapsed when he got acquainted with Khrushchev's secret speech at the $20^{\text {th }}$ party congress of the CPSU in 1956 (see Zudeick 1987, 227). 
However, what we need to leave behind is the way Bloch conceptualizes the overcoming of alienation between humans and their social world and nature in terms of "identity". As Bloch himself understood very well, the implied lack of contradictions and differences would result in an end of history. In order to prevent distant goals assuming (against Bloch's intention) the function of a Kantian "regulative idea", we should conceptualize them as contradictory forms of a movement as well. The summum bonum is to be re-formulated as a dynamic process by which antagonistic contradictions are transformed into non-antagonistic and workable contradictions and differences.

2. In the context of the anti-teleological Zeitgeist of our "postmodern" times, we need to ask whether or in what respect we must de-teleologize Bloch's philosophy or to pluralize its perspective. It appears that Bloch intended to go in this direction as well. In Heritage of Our Times, he tried to uncouple the concept of progress from its linear framework and to connect it to the notion of a "polyrhythmic and multi-spatial" history (Bloch 1991, 62). He later systematized this insight with his concept of a polyphonic spatial temporal "multiverse" (Bloch 1985c, 125, 128-129). The concept of progress is not to be understood in a unilinear way, but needs a "broad, elastic, completely dynamic multiverse, an upholding and entwined counterpoint of historical voices" (Bloch 1985c, 146).

What we need to deconstruct is his "strong" teleology of a "matter driving forward". Bloch is right when he objects to Hegel by stating that nature is no pre-historical "gigantic corpse" (Bloch 1985c, 235), but rather a creative natura naturans, which as an ensemble of efficacious processes permanently engenders new developments, contents and forms. But when Bloch attributes this productivity to a "nature subject," though only a "hypothetical" one, and to an "entelechy," though an "unfinished" one (Bloch 1985a, 461, 476), he brings his ontology in conflict with modern biology, which rightly insists that processes in nature, including the mechanisms of selection discovered by Darwin, are non-teleological. Both the development of nature and human history are to be conceptualized without a big, intentional and directing subject. We do not need a teleology of nature in order to conceptualize a "nature alliance" by which technology connects with nature's productivity in a sustainable way.

But this criticism does not apply to what I conceptualized as Bloch's weak teleological force of open possibilities. The fact that we humans are equipped with the ability to imagine goals and to anticipate future outcomes also means that we are bound to project our thoughts and actions towards objectives. In this sense, we can use Antonio Negri's 
Social movements and political projects need to develop their teleologies (and corresponding genealogies) in order to intervene into the force fields of social purposes. concept of a "teleology of praxis" oriented towards the construction of the common (Negri 2013, 8, 78f). Social movements and political projects need to develop their teleologies (and corresponding genealogies) in order to intervene into the force fields of social purposes. There is no reason to consider this as philosophically objectionable per se, as long as the projected perspective is made transparent.

3. Most of the controversies around Bloch's philosophy touch upon the question of whether his concept of hope is essentialist in the sense that it is conceived as a fundamentally benign and life-affirming force that is only afterwards hijacked and manipulated by the ruling elites. Indeed, we can see some symptomatic blank spaces that seem to corroborate such a suspicion. As feminist critics have pointed out, the patriarchal and oppressive patterns inscribed in everyday wishes usually go unnoticed in Bloch's interpretation (F. Haug 1984, 690-691; see Thürmer-Rohr 1991, 24-27). He is fascinated by the communist "basic resonance" of the biblical Exodus story and the utopian splendor of the Promised Land "flowing with milk and honey", but disregards the account of the book of Joshua about mass butchery that follows the entry of the Israelites into Canaan. When he deals with Christopher Columbus, he focuses on his utopian fantasies of an earthly paradise (Bloch $1986,752,776-777)$, however without considering his role in colonial conquests and their genocidal outcomes. By juxtaposing the "strength and dignity" of Columbus' intention with the later conquests of "criminals Like Cortez and Pizarro" (Bloch 1986, 777), Bloch reproduces a Eurocentric myth. "Also war ships can [...] carry the figurehead of Speranza," argues Beat Dietschy, who proposes a postcolonial deconstruction of Bloch's approach that would start from the "absences of the others, who have been rendered invisible" (Dietschy 2017, 236-237).

These blind spots are symptomatic. Bloch designs the anthropological and ontological foundation of hope on a general philosophical level that tends to dissimulate the fundamental ambivalence of hope in class societies. In actual life, we do not move around as "human species beings," but rather as specific social subjects whose habitus is formed by different class positions, races and genders. In class societies, the fortunes of some go hand in hand with the miseries of others, so that the hopes of some coincide with the despair of the others. It is of course legitimate to conceptualize hope on a general anthropological level as a creative force for the good life for all, but we need to be aware that this is can only be formulated in a mode of possibility. In reality, hope itself is an antagonistic force field traversed by multiple contradictions. Here, we need a stronger "cold stream". Bloch's philosophy needs to be 
combined with a critical theory of ideological subjection, which would in turn help us to de-essentialize his concept of hope. When Bloch argues that hope enables us to throw ourselves actively into what is becoming (Bloch 1986, 1), we also need to take into account how the given structures and fields into which we "throw" ourselves and through which we move, form our wishing, wanting and hoping. The expectant affects are not just "there", but are socially construed and become habituated. Hope can function as an opiate of the people, no less than religion. It can easily be kindled, exploited, and betrayed, e.g. by yes-we-can slogans that are not meant to actually give people the power that would allow them to do what they can. Every time such popular hopes are torched, they risk turning into their opposite, into anxiety, despair, hopelessness, and resentment. What we need is a dialectical approach to hope that is able to discern between empty hope and founded hope. And here, we are of course again on Bloch's own terrain, his specific combination of "cold stream" analysis and "warm stream" goals and impulses.

4. Bloch's anthropological and ontological foundation helps us understand why social emancipation is accompanied and fueled by mass revivals of hopes. One of the most difficult challenges of politics is to understand under what conditions social movements, projects and discourses gain popular appeal and lose it again; set hopes free on a mass scale and disappoint them. Here, it would be fruitful to complement Bloch's philosophy of hope by Gramsci's theory of hegemony, which helps investigate the conditions of both hope and hopelessness. For example, the hegemony of neoliberal capitalism manifested itself in a privatization of hope, by which the dreams of a better world became those for oneself and for one's own family (see Thompson 2013, 5). But this de-socialization of hope is not the last word either. As could be observed e.g. in the Occupy Wall Street movements or in the electoral campaigns of Jeremy Corbyn and Bernie Sanders, popular upswings on a mass scale can once again shift the force-field for hope. ${ }^{3}$ Such a shift can occur when the movement overcomes the neoliberal fragmentations connected to politics of recognition and identitarian silos.

Gramsci has conceptualized such a dynamic with the concept of catharsis. It captures the moment when the subaltern classes and groups overcome their egoistical-corporatist restrictions and empower themselves to build alliances with other subaltern classes. For Gramsci, this cathartic moment was so significant that he declared it to be "the star-

3 For a Gramscian analysis of the Occupy movements and the Bernie Sanders Campaign 2016, see Rehmann 2013 and 2016.
Bloch's philosophy needs to be combined with a critical theory of ideological subjection, which would in turn help us to de-essentialize his concept of hope. 
ting-point for all the philosophy of praxis". It marks the point where the subaltern classes transition from "objective to subjective" and from "necessity to freedom;" from being a passive "object" of social conditions to becoming an active historical subject (Gramsci 1971, 366-367; Gramsci 1975,1244$)$. It is in these cathartic moments that hope, whose anthropological and ontological foundations Bloch has so beautifully reconstructed, can emerge concretely. In our neoliberal constellation, hope can be redefined as the cathartic effect of the confluence of dispersed and fragmented subaltern subjects towards a common project of transformation that does not negate its inner contradictions but finds ways to bring them into a productive arrangement.

Referring back to the starting point of my argument, I hope to have shown that the widespread classification of Bloch as a utopian, eschatological, romantic, idealistic, mystical thinker misses both the operative strategy by which he intervened in the contentious force field of contemporary Marxism and the relevance of his philosophy for today's social struggles and movements. The characteristics of Bloch's philosophy can best be deciphered by a praxis-philosophical re-reading that focuses on his specific contribution to the development of both an anticipatory capacity to act and an awareness of open possibilities. But to work with Bloch's philosophy today also requires developing it further. It is in this vein that I propose to reformulate Bloch's "highest good" in terms of a contradictory process of reconciliation. His concept of hope can be de-essentialized by combining it with a critical theory of ideology. Following Bloch's own concept of a "multiverse", his teleological understanding of history is to be pluralized and de-linearized. In particular, Gramsci's theory of hegemony and "catharsis" helps to identify the conditions of both hope and hopelessness, thus opening up Bloch's philosophical foundation to social and political analysis.

\section{References}

Adorno, Theodor. 1991. Notes to Literature I, edited by Rolf Tiedemann. Translated by Shierry Weber Nicholsen. New York: Columbia University Press.

Benjamin, Walter. 2007/1940. "Theses on the Philosophy of History." In Illuminations. Essays and Reflections, 253-264. New York: Schocken Books. 
Bloch, Ernst 1975. Gespräche mit Ernst Bloch, edited by Rainer Traub and Harald Wieser. Frankfurt am Main: Suhrkamp. . 1985a [1972]. Das Materialismusproblem, seine Geschichte und Substanz. Gesamtausgabe, Vol. 7. Frankfurt am Main: Suhrkamp. . 1985b [1965]. Literarische Aufsätze. Gesamtausgabe, Vol. 9. Frankfurt am Main: Suhrkamp.

—. 1985c [1963]. Tübinger Einleitung in die Philosophie. Gesamtausgabe, Vol. 13. Frankfurt am Main: Suhrkamp.

-. 1985d [1975]. Experimentum Mundi. Frage, Kategorien des Herausbringens, Praxis Gesamtausgabe, Vol. 15. Frankfurt am Main: Suhrkamp.

1986. The Principle of Hope, translated by Neville Plaice, Stephen Plaice, and Paul Knight. Cambridge (MA): MIT Press.

-1991. Heritage of Our Times, translated by Neville and Stephen Plaice. London: Polity Press.

Braun, Eberhard. 1983. "Antizipation des Seins wie Utopie. Zur Grundlegung der Ontologie des Noch-Nicht-Seins im 'Prinzip Hoffnung." In Seminar zur Philosophie Ernst Blochs, edited by Burghart Schmidt. Frankfurt am Main: Suhrkamp.

Dietschy, Beat. 1988. Gebrochene Gegenwart. Ernst Bloch, Ungleichzeitigkeit und das Geschichtsbild der Moderne. Frankfurt am Main: Vervuert.

- 2017. "Wunschlandschaften, entdeckt und gebildet." In Bloch-Wörterbuch. Leitbegriffe der Philosophie Ernst Blochs, edited by Beat Dietschy, Doris Zeilinger, Rainer Zimmermann, 227-52. Berlin-Boston: De Gruyter.

—. 2018. "Im Mischdunkel nationaler Berauschung. Ernst Blochs Erbschaft dieser Zeit, in Zeiten des Rechtspopulismus gelesen.” Das Argument 325: 31-44.

Dietschy, Beat, Doris Zeilinger, Rainer Zimmermann, Eds. 2012. Bloch- Wörterbuch. Leitbegriffe der Philosophie Ernst Blochs. Berlin-Boston: De Gruyter.

Dussel, Enrique. 2013. Ethics of Liberation in the Age of Globalization and Exclusion, Durham, NC: Duke University Press.

Eagleton, Terry. 2015. Hope without Optimism. Charlottesville: University of Virginia Press.

Foster, John Bellamy, Brett Clark, Richard York. 2010. The Ecological Rift. Capitalism's War on the Earth. New York: NYU Press.

Gramsci, Antonio. 1971. Selections from the Prison Notebooks of Antonio Gramsci, edited and translated by Qunitin Hoare and Geoffrey Nowell Smith. New York, NY: International Publishers. 
1975. Quaderni del carcere. Four volumes, critical edition of the Gramsci Institute, edited by V. Gerratana. Torino: Einaudi.

Habermas, Jürgen. 1985. Die neue Unübersichtlichkeit. Kleine politische Schriften V. Frankfurt am Main: Suhrkamp.

Haug, Frigga. 1984. "Tagträume - Dimensionen weiblichen Widerstands." Das Argument 147: 681-98.

Haug, Wolfgang Fritz. 2017. "In der Höhle des Löwen. Kann man das "Kapital" von den Feuerbach-Thesen her lesen?." Das Argument 322: $1-12$.

Holz, Hans Heinz. 2012. "Spekulativer Materialismus". In Bloch-Wörterbuch. Leitbegriffe der Philosophie Ernst Blochs, edited by Beat Dietschy, Doris Zeilinger, Rainer Zimmermann, 483-508. Berlin-Boston: De Gruyter.

Holzkamp, Klaus. 1985. Grundlegung der Psychologie. Frankfurt am Main: Campus.

Luxemburg, Rosa. 1970-1975. Gesammelte Werke, 5 Volumes, edited by Institut für Marxismus-Leninismus beim ZK der SED, Berlin/ DDR: Karl Dietz Verlag.

Marx, Karl. 1845. "Theses on Feuerbach.” In Marx Engels Collected Works, vol. 5. London: Lawrence \& Wishart.

- 1976, Capital. A Critique of Political Economy, vol. I, translated by Ben Fowkes. London: Penguin Books.

Marx, Karl and Friedrich Engels. 1975-2005. Marx Engels Collected Works (MECW). London: Lawrence \& Wishart [quoted as MECW].

Moir, Cat. 2019. Ernst Bloch's Speculative Materialism. Ontology, Epistemology, Politics. Leiden, Boston: Brill.

Negri, Antonio. 2013. Spinoza for our Time: Politics and Postmodernity. New York: Columbia University Press.

Rehmann, Jan. 2012. "Antizipation.” In Bloch-Wörterbuch. Leitbegriffe der Philosophie Ernst Blochs, edited by Beat Dietschy, Doris Zeilinger, Rainer Zimmermann, 3-13. Berlin-Boston: De Gruyter.

. 2013. "Occupy Wall Street and the Question of Hegemony - A Gramscian Analysis." Socialism and Democracy 27, no. 1 (March): $1-18$.

- 2014. Theories of Ideology. The Powers of Alienation and Subjection. Chicago: Haymarket.

- 2016. "Bernie Sanders and the Hegemonic Crisis of Neoliberal Capitalism: What Next?." Socialism and Democracy 30, no. 3, $1-11$.

Schiller, Hans-Ernst. 2017. Freud-Kritik von links. Bloch, Fromm, Adorno, Horkheimer, Marcuse. Hamburg: Zu Klampen! Verlag. 
Schmidt, Burghart, Ed. 1983. Seminar zur Philosophie Ernst Blochs. Frankfurt am Main: Suhrkamp.

Siebers, Johan. 1983. "Ultimum." In Bloch-Wörterbuch. Leitbegriffe der Philosophie Ernst Blochs, edited by Beat Dietschy, Doris Zeilinger, Rainer Zimmermann, 582-89. Berlin-Boston: De Gruyter.

Thompson, Peter. 2013. "Introduction: The Privatization of Hope. Ernst Bloch and the Critics of Negation". In The Privatization of Hope. Ernst Bloch and the Future of Utopia, edited by Peter Thompson and Slavoj Žižek. Durham-London: Duke University Press.

Thürmer-Rohr, Christine. 1991. Vagabonding. Feminist Thinking Cut Loose. Boston: Bacon Press.

Zimmermann, Rainer E., Ed.. 2017. Ernst Bloch: Das Prinzip Hoffnung, Berlin-Boston: De Gruyter.

Zudeick, Peter. 1987. Der Hintern des Teufels. Ernst Bloch - Leben und Werk. Moss u. Baden-Baden: Elster Verlag. 
JAN REHMANN - is Dr. phil. habil, Visiting Professor for Critical Theory and Social Analysis at Union Theological Seminary in New York, Privatdozent at the Free University in Berlin; co-editor of the Historical-Critical Dictionary of Marxism (HKWM); books: Deconstructing Postmodern Nietzscheanism: Deleuze and Foucault (forthcoming); Max Weber. Modernisation as Passive Revolution. A Gramscian Analysis (2015); Theories of Ideology. The Powers of Alienation and Subjection (2013); Pedagogy of the Poor (2011); together with Willie Baptist); The Churches in Nazi Germany (1986).

\section{Address:}

Union Theological Seminary

99 Claremont Ave \#502

New York, 10027

email: janrehmann@aol.com

Citation: Rehmann, Jan. 2020. “Ernst Bloch as a Philosopher of Praxis”. Praktyka Teoretyczna 1(35): 75-94.

DOI:10.14746/prt2020.1.5

\section{Autor: Jan Rehmann \\ Tytuł: Ernst Bloch jako filozof praktyczny}

Abstrakt: Wbrew szeroko rozpowszechnionemu ujęciu filozofii Blocha, w ramach którego określana jest ona jako „mistyczna”, „eschatologiczna”, „idealistyczna” itd., niniejszy tekst pokazuje, że najlepszą drogą interpretacji tej myśli jest jej interpretacja przez pryzmat marksistowskiej filozofii praktycznej. Podobnie jak Labriola i Gramsci, Bloch rozwija swoje pojęcie materializmu w oparciu o Marksowskie Tezy o Feuerbachu. Jego koncepcje „najwyższego dobra” i „techniki sojuszu” podejmują perspektywę pojednania pomiędzy ludźmi i naturą, bliską młodemu Marksowi; jego teoria antycypacji i nadziei skupia się na rozwoju kolektywnych możliwości działania; nawet jego „ontologia jeszcze-nie”, często krytykowana za teleologiczność, jest tak naprawdę oparta na pojęciu „otwartych możliwości” i tym samym może być interpretowana w ramach „słabej siły teleologicznej” przynależącej ludzkiej sprawczości. Niemniej jednak z perspektywy praktyczno-filozoficznej widać, że filozofia Blocha musi również zostać przemyślana na nowo w sposób, który uporałby się z jej esencjalistycznymi założeniami i zróżnicowałby jej teleologię.

Słowa kluczowe: antycypacja, hegemonia, nadzieja, ontologia, teleologia 